Grundzüge zu Vorlesungen

über

\title{
Eiserne Balkenbrücken.
}





\title{
Grundzüge zu Vorlesungen
}

\author{
über \\ Eiserne Balkenbrücken \\ von
}

Ferdinand Loewe,

Professor der Ingenieurwissenschaften am kgl. Polytechnikum in Mánchen.

Mit 80 Abbildungen.

München.

Druck und Verlag von R. Oldenbourg.

1877. 
Uebersetzungsrecht vorbehalten. 